\title{
Townships and Large Housing Schemes: The Case of Ahmedabad
}

\author{
Kahinee Shah
}

\begin{abstract}
Ahmedabad has always been a hub for the real estate sector. Private developers have come up with affordable housing schemes and townships in the western part of the city. The concept of an integrated township was introduced in Gujarat with the first township policy in 2006 by GUDC. A new residential township policy was again introduced in 2009 with changes concerning bank guarantee and minimum area of the township. Looking at the kind of investment and the kind of approvals needed, many developers prefer developing housing schemes. But many fiscal and FSI benefits mentioned in the township policy also attract them. People often look at the benefits of a township pertaining to its scale and the kind of lifestyle it promises to offer. But what we overlook is the developer's perspective linked with its institutional framework. This research highlights and focuses on behind the scene aspects for both the developments and their processes.
\end{abstract}

Keywords-Property Development Process, Townships, Stand-alone schemes, Time and Cost, Private sector.

\section{INTRODUCTION}

\section{Background}

Limited housing supply has been a point of concern in Indian context. According to the estimates of Technical Group constituted by Ministry of Housing and Urban Poverty Alleviation (MHUPA), urban housing shortage during the $11^{\text {th }}$ five year plan, at the end of 2012, was 18.78 million in urban areas and 43.67 million units in rural areas, with $95 \%$ of the total pertaining to EWS ${ }^{\text {ii }}$ and $\mathrm{LIG}^{\mathrm{iii} 1}$. According to Cushman \& Wakefield Research, the total housing demand in the country by 2017 could be as high as 88.78 million units. Around $23 \%$ of this total demand will be generated in the top eight cities of India. Of the 18.78 million units to be required the township projects are collectively promoting their projects to a market accounting for only $0.16 \%$ of the total people affected by housing shortage. A report by McKinsey states that 20 metros and cities across the country need to build around 20-25 new townships closer to them. In Ahmedabad also, housing shortage has led to increasing slum population in the city. The official estimates by the $\mathrm{AMC}^{\mathrm{iv}}$ of the proportion of slum population are: 16.0 per cent $(0.46$ million $)$ in $1991,25.8$ per cent $(0.91$ million) in 2001 (AMC 2005) and 13.0 per cent ( 0.73 million) in 2010. The latest estimate of 17 chawls in the AMC area is 958 (consisting of textile mills' chawls and new low-income housing), which house around 149,002 households (AUDA ${ }^{\mathrm{v}}$

Kahinee Shah is with CEPT University, India

${ }^{1}$ Alleviation, Ministry of Housing \& Urban Poverty. "Annual Report." 2011-2012
2013). ${ }^{2}$ Public and private sector interventions, due to the slow development and few drawbacks, still fail to reduce the demand. The public sector reforms include government policies and programs implemented at central and state level. Many of these programs are PPP ventures. The private sector actions include the development of

1) Stand-alone schemes based on GTPUDA ACT vi , Development Plan (DP) and building by-laws

2) Integrated township models based on the state integrated township policies.

These two private sector models of development have their own institutional and implementation framework. Many stand-alone affordable housing schemes and other large scale housing schemes have been prevalent in the city. AMC, AUDA and the revenue department play a very important role in the process development of these projects. These schemes are developed based on the zoning and land prices in the area. The townships can be developed in any zone, but because of the large area under development many of them have been sanctioned in the outskirts of the city. Under the Gujarat Integrated Township Policy, these townships can have fiscal benefits from the government. Apart from the local authorities, the state government interferes in the approval process. Now this concept of township with more investment and a prolonged completion time, attracts few developers only. Time and cost have a major impact on this type of development. In this context, this research aims to compare the property development process for the two different development models.

\section{Aim}

To compare the property development process of townships to large scale housing schemes.

\section{Objective}

- To study the framework for property development process in Integrated Township and Large housing schemes.

- To carry out a comparative assessment and understand their impact on time and cost.

\section{Overview of Integrated townships}

Although the word township has been commonly used, there is no one nationally accepted definition or format. Therefore anything from 25 to 2500 acres qualifies or is termed as a township. In the past India has witnessed various types of

\footnotetext{
${ }^{2}$ Biometric socio-economic household level survey, as quoted in AMC and PAS 2010. "Slum Free Cities: A Case for Ahmedabad," Presentation at the Workshop to Advance City-Wide Strategies for Slum Upgrading, CEPT University, Ahmedabad, August 13, 2010.
} 
models as far as townships are concerned. After independence, eastern India saw the emergence of industrial towns like Jamshedpur, Bhilai, Rourkela, Durgapur etc. These townships have corporate or industry promoters running their administration and services, but with the consent of the respective governmental authorities. Besides this, several cities have emerged from the design boards like Bhubaneswar, Chandigarh, and Gandhinagar. Thereafter, the country saw a series of satellite towns like Faridabad, Gurgaon etc. and sub cities namely Dwarka, Rohini, Navi Mumbai etc. come up. It is the ever increasing urbanization that also gave rise to residential townships in different states of India. From 2001-2006 the different township policies in Lucknow, Maharashtra, Uttar Pradesh, Gujarat, Andhra Pradesh put forward their first attempts to form the township policies. Since then there have been many changes and reforms in the policies. Different agencies, consultants, developers have given varied estimates about the number and extent of townships that have either been constructed or are been planned for the future. According to the MoEF(Ministry of Environment and Forests), since 2006, 39 township projects have been granted environmental clearance3. According to EIA (Environmental Impact Assessment) notification any area development and township projects above 50 acres have to get environmental clearance from the MOEF.

Township projects also seem to have won favours from both national and foreign investors. Real estate consultancy and research firm, Jones Lang LaSalle (JLL) reported that the international investors since 2006 have put in about US\$ 15.8 billion in this sector. Of which, US\$ 2.7 billion went to residential projects and US\$2.4 billion to township projects, which is the second highest investment amongst all types of projects, while rest went into commercial, SEZ projects etc. In case of private equity, township projects have received investment of nearly US\$ 122 million by 2011, which is also on the higher side. ${ }^{4}$

There is no denying the fact that the integrated townships are going to have sizable impact on the urban development scenario. Therefore, it is most logical and appropriate to have a strategy and a policy in place to deal with its regulation and monitoring. These policies need to ensure that the all important principles of inclusiveness, equity, environmental sustainability and transparency are addressed adequately in these policies. Further, it is important to have adequate clarity and harmony amongst the state and the central government's policies and perspectives dealing with integrated townships to ensure that the development is regulated and has proper directions.

\section{Overview of Gujarat Residential Township Policy (2009)}

The Gujarat Integrated Township Policy defines township as any multi-functional node such as housing, social, educational and welfare institutions, commerce and entertainment complexes and non-polluting industries premises within cities and urban centers of the state as counter magnets to the

\footnotetext{
3 MoEF's response to CSE's RTI, http://cseindia.org/content/conspiracy-silence

${ }^{4}$ Anon, 2011, Real Estate, Indian Brand Equity Foundation, November, www.ibef.org
}

congested cores and aimed to augment the respective deficits in the region.

\section{Government's Role}

- Green Channel: The developer of the township will be allowed self-certification, deemed clearance (such as NA on qualification of township), and time limit for clearances.

- Single Window: A single window or dual window system would be created for the scales of townships.

- Land Assemblage: The developers do majority of the land assemblage. The government will intervene only if required for residential assemblage through compulsory acquisition or by consent for which the framework will be set in terms of fair price valuation committee. To facilitate the developer's initiative for land assemblage the government will consider grant of permission for bonafide townships, new tenure premium rationalization, government lands on lease, land parcels subject to Charity Commissioner's jurisdiction and registered as charities (GAUSHALA), WAKF lands, Devasthan inam lands, Prasayata Inam lands, Khar lands etc.

\section{Fiscal Incentives}

Pre Development exemptions extended to the developer such as Stamp Duty Exemptions, Tax waivers on construction material, scrutiny fees etc. Post development exemptions extended to the individual plot owners such as Entertainment Tax waivers, Luxury Tax waivers etc.

\section{Special Benefits}

- The government can enter into a PPP agreement with the developer on extension of government land, infrastructure or assets for the townships. Since the project is approved under the township policy, the advantage of the NA clearance is, that a specific parcel of land, which is to be developed, need not be NA. For e.g. For a 100 acre of township, If 40 acres of cluster is to be developed, NA conversion for an equivalent area of land across the whole township is acceptable. However by the end of complete development of 100 acres, the land parcel as a whole must be NA. The conversion is done under the Bombay Land Revenue Code, 1879 as applicable to Gujarat and the Gujarat Land Revenue rules, 1972. The charges payable to the authority are $80 \%$ of the rate mentioned in the Annual Schedule of Rates (ASR). Non-agriculture permission will be automatic

- Exemption from Urban Land ceiling and Regulation Act, 1976

- Government land falling under township area, leased out to the developer at the current market rate

- Floating FSI in the township

- $50 \%$ concession in development charge

\section{FSI regime}

The township will be allowed in a blanket FSI of 2.25 on gross site +0.25 additional development rights (ADR) subject to payment of premium plus compensatory FSI for EWS housing. (2006) Total FSI permitted on Gross plot area shall be sum of Global FSI and Additional FSI as under; (2009). Global FSI (GFSI) shall be 1.0

\section{Overview of townships in Ahmedabad}


The "Integrated Township Policy" was introduced in 2006. This policy was revised in 2009 under "The Residential Township Policy". In 2008, the AUDA and the state screening committee appointed to review the proposal for township, gave approval to 5 townships, of the 9 proposals submitted. The committee held back four major township projects. The townships need an approval from the state government as well as from AUDA. The screening committee issued final order to one township, while four township projects received in-principle approval. (Received approval only from AUDA).

\begin{tabular}{|l|l|}
\hline Townships & Approval Status (2008) \\
\hline Applewood & Approved \\
\hline Arvind's group township (Moti Bhoyan) & In-principle \\
\hline Shantigram & In-principle \\
\hline Sahara City & In-principle \\
\hline Safal Group's township near Sanand & In-principle \\
\hline Arvind's group township (Jethlaj) & Not approved \\
\hline Godrej Garden City & Not approved \\
\hline Smile City & Not approved \\
\hline Ozone Group's township(Santej) & Not approved \\
\hline
\end{tabular}

Arvind Group's township project fell under the buffer zone for a bird sanctuary, so the company was asked to obtain clearance from forest and environment department. Moreover, the canal adjoining Ganesh Housing's Smile City Golf Township became a hindrance to the project. The township projects of Godrej and Ozone were in the same year (2010) not given approval for some technical reasons. Post this, the committee made it mandatory to make a six monthly review of the progress of the project. It also stated that in the first phase of the development, the developer of the township has to, with the prior permission of the screening committee, construct the first draft of the town planning or TP road.

By 20158 townships were given the final order approval which are currently in their various phases of development.

- Arvind Smart Value Home LLP

- $\quad$ Applewoods (Sandesh Ltd)

- $\quad$ Sky city (Sahara city)-(H N safal and Goyal)

- $\quad$ Super city (K .B Zaveri and Shrinivas )

- Shantigram

- Godrej garden City

- $\quad$ Arvind Group's project at Jethlaj

- Arvind Group's township at Moti Bhoyan

\section{Site Selection}

Of the 8 approved townships in Ahmedabad as of 2015, Godrej garden city is selected as the first case study. The site is within AMC limits, hence can be compared to the framework of any large housing schemes within the limit. Also, spread over an area of 210 acre $(8,49,840)$, it is one of the few townships which has completed planning for $70 \%$ of the area(149 acres) and developed $40 \%$ of it (57 acres).

The second case study selected is, Bakeri City spread over an area of 140 acres, a large housing scheme with basic amenities, also within the AMC limits.

\section{Site-1: Godrej garden city}

\section{General details and Stages of development}

Total Area: 210 acres
NA land: 84 acres

Planned: 149 acres

Developed: 57 acres

Total phases: 5

Anticipated completion in year: 2020

The development process for Godrej garden city started 7 years ago (2009). The concept of "Integrated" township gave a different character to the project. The idea was to give access to amenities within the township so that the people would confine most of their time within the township itself.

\section{Land Assembly}

Godrej as a company does not invest into land parcels. They prefer joint ventures for large project like the garden city. For this project particularly, they entered into a joint venture with a private party Shree Siddhi Group. For liquidity of the project, the land was owned by the joint venture partner i.e. Shree Siddhi Group. They own 210 acres of land dedicated to the project.

\section{Procedure for notification and securing permission}

A prescribed officer by the state government, who is a member of the local body or development authority (AUDA in this case) shall carryout survey and studies for any area to be considered for township development and recommend to the government to declare any area, to be a notified area.

Subject to the provisions of the township policy and the GDCR, the state level screening committee reviewed the proposal received from AUDA (prescribed officer) for Goderej Garden City. The same was given the gazette notification under the policy in 2009 by the State government. After applying to the state government for the proposal, they were given the permission to secure in 2009.After getting all the necessary approvals, they commenced the development in September 2010.

\section{Maintenance}

At cluster level and individual tower level separate societies are formed. An apex society under the Godrej group is formed, which monitors the maintenance of these separate societies and looks after amenities and infrastructure outside these clusters. For public parks, they maintain it for 7 years (according to the policy) and then hand it over to AMC

\section{Site-2: Bakeri City}

\section{General details and stages of development}

Total Land area bought: 5, 43,056 sq.mt.(134.19 acres)

Land in possession: 4, 79,000 sq.mt. (118.3 acres)

Land sold to developers: 2, 25,263 sq.mt (55.66 acres)

Remaining Land: 2, 53,737 sq.mt (62.69 acres)

Developed: 1, 88,709 sq.mt (46.63 acres)

Total schemes: 19 (1 commercial)

Bakeri Group became active in the Vejalpur area during 1991.The project came to be known as the Shrinandnagar township until in 2008, when they changed it to Bakeri City. Spread over an area of 140 acres, the housing scheme is one of the oldest housing projects in the city. 


\section{Detailed Framework of Bakeri City \& Godrej Garden City:}

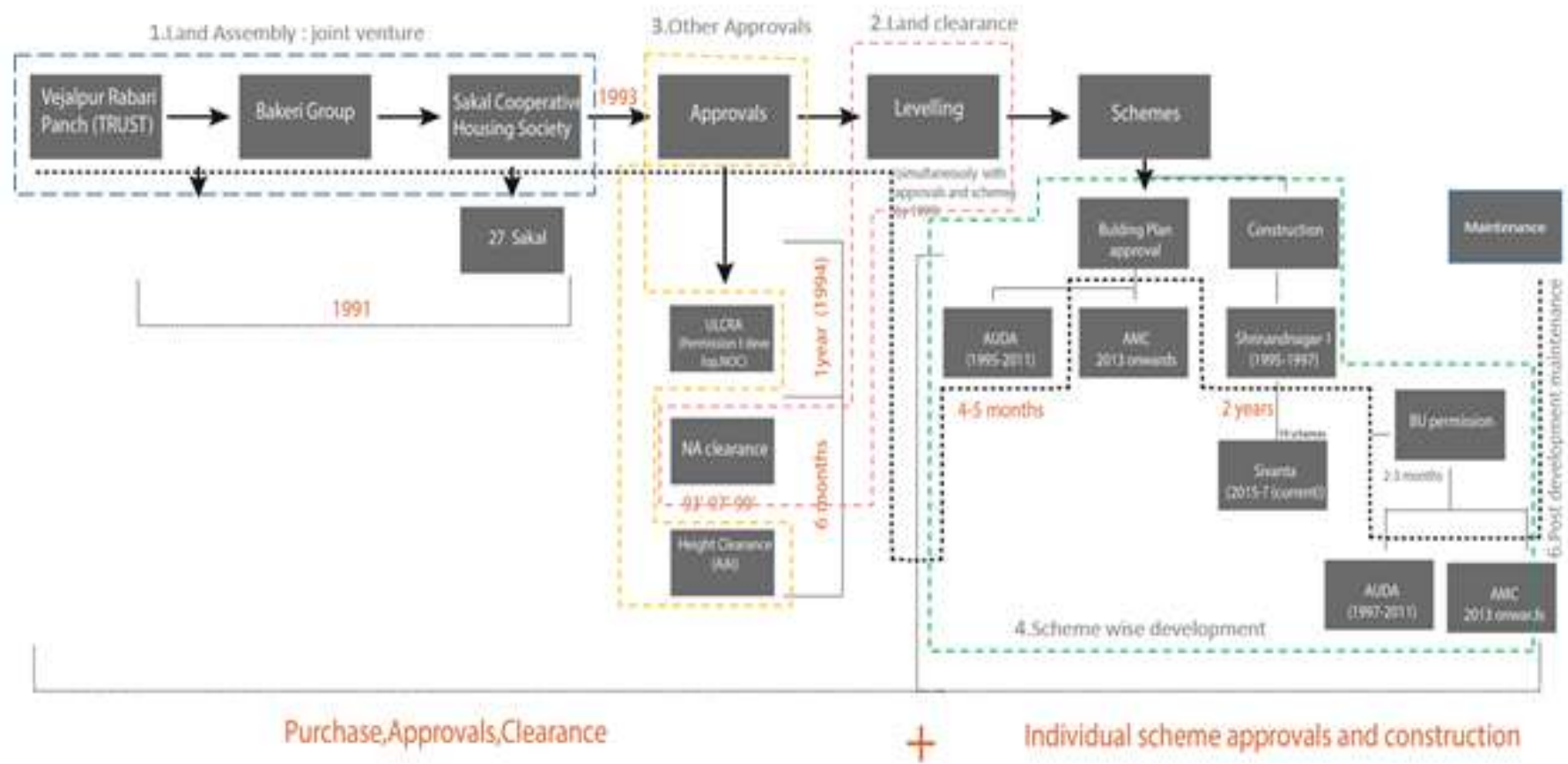

Fig. 1: Detailed framework of Bakeri City

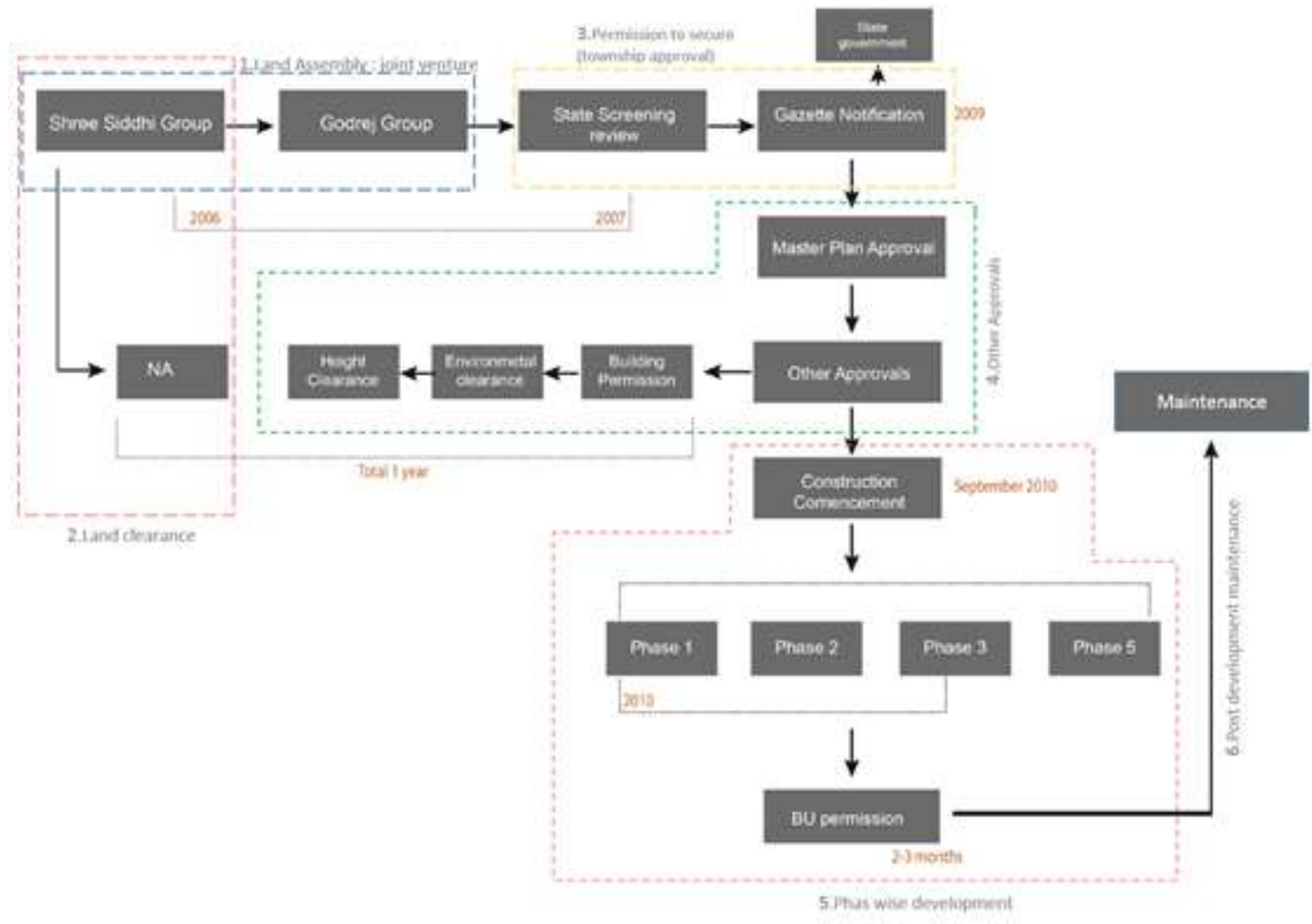

Fig. 2: Detailed framework of Godrej Garden City

\section{Land Assembly}

Bakeri group bought a land in Vejalpur area from the Vejalpur rabari panch (trust) in July 1991.The area of the land was 543056 sq. mt. They formed a Sakal cooperative housing society in 1991 under which they signed the agreement with the trust to buy the land. The land was further subdivided into 27 equal parts-27152 sq. mt each for transfer of property and ownership. As mentioned in the ULCA (urban Land ceiling Act, 
1976), the price at which the land was to be sold, was decided by the government. This land was sold at $25 \mathrm{Rs} / \mathrm{sq}$. mt. After applying for permission to develop under the ULCRA(Urban Land Ceiling and Regulation Act), they got the approval in 1994.

\section{Land Clearance}

NA clearance-The land was converted to nonagricultural land first in 1994 followed by 1997 and 1999.Each time the period was 6 months. It took 2-3 years for the land approvals and clearances followed by the levelling of the entire land parcel which took another 8 years.

\section{Maintenance}

The developers are in charge of the maintenance for 3 years and then they hand it over to the authority. The internal roads, water and sewage facilities are provided by the AMC.

Analysis

\section{Comparable parameters for the two cases:}

Godrej garden city, a township approved under the state township policy and Bakeri City, a large housing scheme, have different parameters that affect the completion time and the cost of project. For two different entities, they can be compared by the following parameters:

1) Parameters Affecting Time:

Approvals

Phase-wise construction

2) Parameters Affecting Cost:

FSI and Built up

Developer's role

Project Cost

\section{Parameters Affecting Time}

\section{Approvals}

TABLE I: Approval comparison of two sites

\begin{tabular}{|l|l|l|}
\hline Approvals & Godrej Garden City & Bakeri City \\
\hline $\begin{array}{l}\text { State approval for Gazette } \\
\text { notification }\end{array}$ & 2 years & \\
\hline $\begin{array}{l}\text { Development permission } \\
\text { under the Urban Land } \\
\text { Ceiling And Regulation }\end{array}$ & & 1 year \\
\hline
\end{tabular}

\begin{tabular}{|l|l|l|} 
Act,1976 & & \\
\hline $\begin{array}{l}\text { Non-agriculture } \\
\text { permission }\end{array}$ & 3 months (automatic) & $\begin{array}{l}6 \quad \text { months } \\
\text { (subdivided land) }\end{array}$ \\
\hline $\begin{array}{l}\text { Master Plan } \\
\text { Approval/building plan }\end{array}$ & 4 months (phase wise) & $\begin{array}{l}4 \text { months } \\
\text { (scheme wise) }\end{array}$ \\
\hline Environmental clearance & Almost 8 months-1 year & \\
\hline Height clearance & 6 months & \\
\hline
\end{tabular}

\section{Possible interventions}

Environment clearance is mandatory for projects of/above size 20,000 square meters and township projects having more than $50 \mathrm{HA}$ area. Environment clearance is a pre-requisite for Building Plan approval. Getting the environment clearance is a lengthy process which often takes 8 months to 1 year presently. This delays the approval of building plan and therefore further approvals and NOCs. The environmental clearance should be obtained by the local authority (e.g. AUDA) for the entire DP (Development Plan) and the Town Planning Scheme (TPS) should be strictly based on this plan. Developers need not obtain separate environment clearances for individual projects if the project is if the project is planned according to the DP \& TPS. This will hugely save time and costs of projects.

If the project is planned as per the DP since it is already zoned for the concerned activity, the requirement of NA permission for real estate projects could be condoned. Deemed clearances must be given wherever there is a delay in giving approvals. The NOC from Airports Authority of India takes about 6 months and could be relaxed selectively. DP should clearly mark the areas which would require AAI clearance for projects, area outside this need not require AAI NOC and be free to develop as per the DP and TP scheme.

\section{Phase wise construction}

TABLE 3: Built comparison for a comparable year

\begin{tabular}{|l|c|c|}
\hline Category & Godrej Garden City & Bakeri City \\
\hline Total Phases/Schemes & 5 & 19 \\
\hline Total no. of units & 3420 & 5574 \\
\hline No of units ready & 2184 & 5574 \\
\hline Time to complete the & $2006-2020(14$ & $1991-2015$ (19 \\
entire project & years-anticipated) & years) \\
\hline Comparable year & Upto 2016 (2184 & Upto 2001 ( \\
& units) & 2160 units) \\
\hline Type (BHK) & $1,2,3,3.5$ & $1,2,3,1 \mathrm{HK}$ \\
\hline Area developed (sq. & 230671 & 68425 \\
mts) & & \\
\hline
\end{tabular}




\section{Bakeri City}

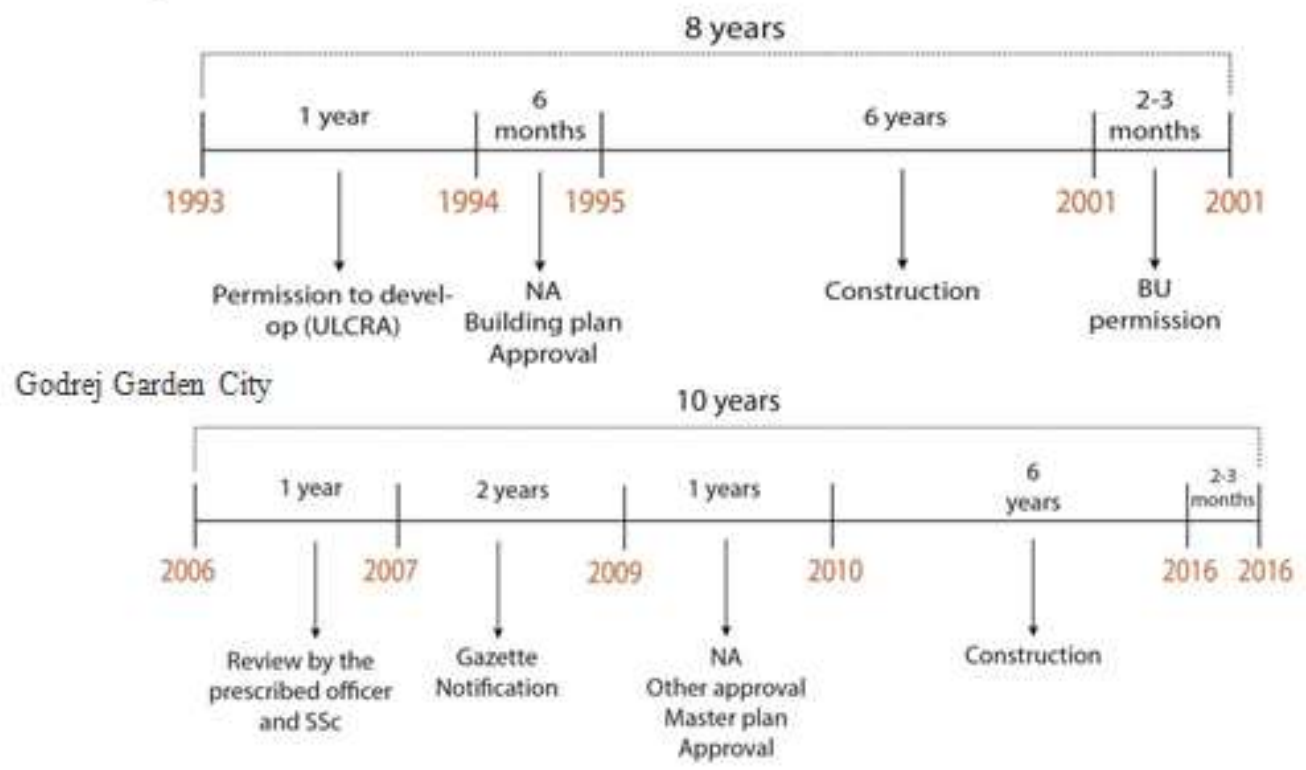

Fig. 3: Project completion time

The 2 years gap for Godrej Garden city is due to the delay in permission to secure (Gazette notification). The same process for the housing society took 1 year. Also since it is spread over a huge area, it needs to be approved of clearances that Bakeri city is not compelled to.

\section{Parameters Affecting Cost}

\section{FSI and Built up}

TABLE II: Earning Potential calculations

\begin{tabular}{|l|l|l|}
\hline Data & Bakeri city (2016) & $\begin{array}{l}\text { Godrej } \\
\text { (by2020) }\end{array}$ \\
\hline $\begin{array}{l}\text { Total residential area (super built } \\
\text { up) (sq. mt) }\end{array}$ & $332,040.00$ & 1183704.75 \\
\hline Total built up(sq. mt) & $456,726.60$ & $1,727,640.00$ \\
\hline \% area residential & 72.70 & $68.5 \%$ \\
\hline FSI & 1.80 & 2.25 \\
\hline Basic sale price (current) & 35,885 & $31,000.00$ \\
\hline Project Cost(Rs) & $7,198,530,000.00$ & $46,712,340,00$ \\
\hline Earning potential (Rs) & 46959.08 & 47789.705 \\
\hline
\end{tabular}

The FSI and built up for a project can be used to find out the earning potential for a project.

Earning Potential (residential): \%area *FSI* Basic sale price The basic sale price is considered for the current year. The earning potential and the basic sale price are directly proportional and hence by 2020 it would increase proportionately. Godrej Garden City has a higher earning potential due to higher FSI. The earning potential cannot be increased by simply increasing the selling price of the property. While Bakeri city has a high earning potential due to the higher basic sale price of the land.

As mentioned above, Godrej garden city produced the same number of units in 10 years that Bakeri City constructed in 8 years. However the area developed by Garden city was much higher. If the 2 year lapse could have been saved, the following could have been the earning potential of Godrej Garden City by 2016 .

TABLE III: Possible scenario of earning potential for Godrej garden City

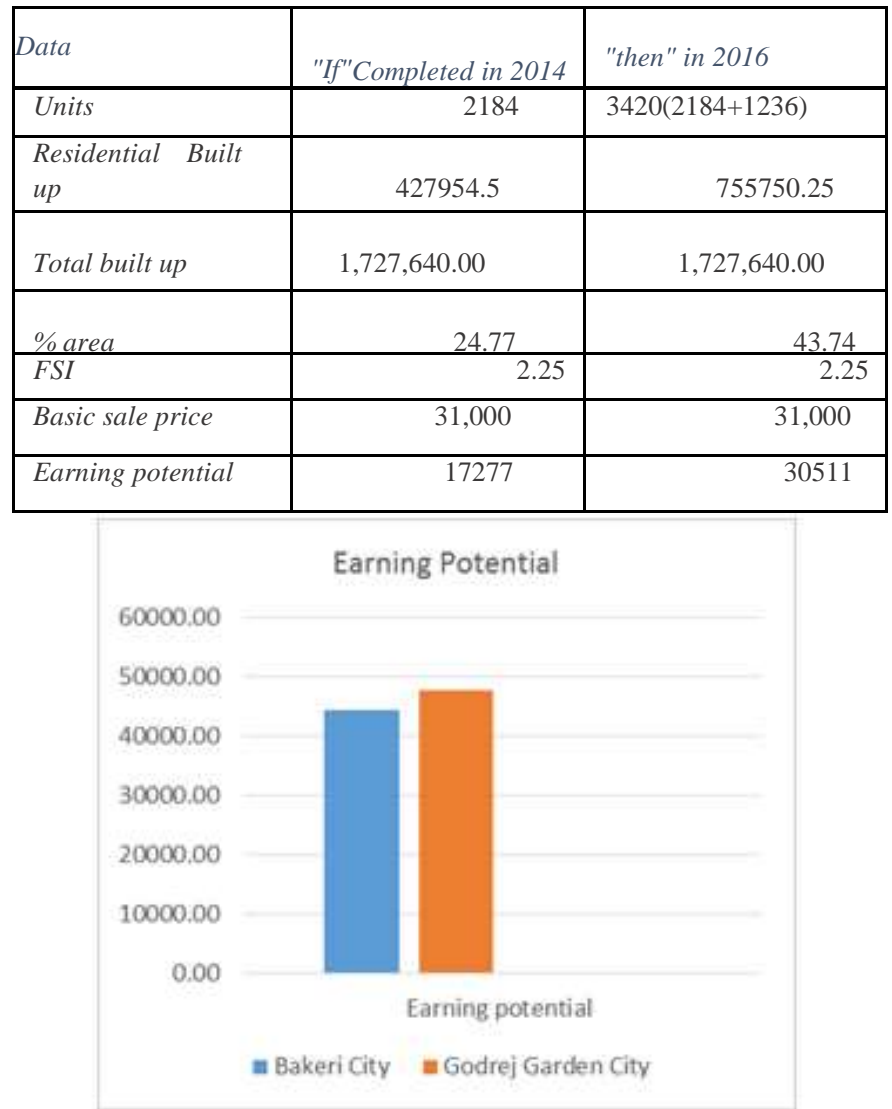

Fig. 4: Earning potential for two case studies 


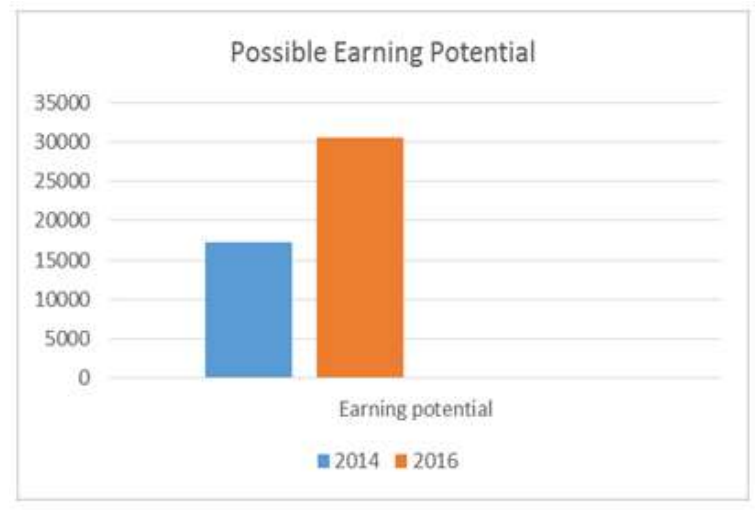

Fig. 5: Possible earning potential for Godrej Garden City

Again the result has been derived by keeping a constant sale price. This price would increase by $15-20 \%$ every year (primary survey of developers in Bakeri group). The anticipated date for project completion for Garden City is 2020.In the current year, the potential is 17277; the table shows the outcome, if it would have completed by 2014 and then followed by 2016. The earning potential right now (17277) is almost half as much as it could have been (30511).

\section{Developers Role}

TABLE IV: Project cost bared by the developers in both the case studies.

\begin{tabular}{|l|l|l|}
\hline & Godrej Garden City & Bakeri City \\
\hline $\begin{array}{l}\text { Offsite } \\
\text { infrastructure }\end{array}$ & $\begin{array}{l}\text { Developer bears the } \\
\text { entire cost }\end{array}$ & $\begin{array}{l}\text { Developer pays } \\
\text { betterment and } \\
\text { development charges } \\
\text { for 40\% of the } \\
\text { surrendered land }\end{array}$ \\
\hline Maintenance Cost & $\begin{array}{l}\text { The developer bears for } \\
\text { at least 7 } \\
\text { years (policy) }\end{array}$ & $\begin{array}{l}\text { The developer } \\
\text { voluntarily bears for the } \\
\text { first three years on an } \\
\text { average }\end{array}$ \\
\hline
\end{tabular}

\section{Project Cost comparison}

Here a 3bhk unit from having almost the same area are compared on bases of the additional cost along with the net cost of the unit. The difference in the net cost of the unit for the township and Bakeri city is less. But area development charges, club house charges and higher service tax are charged for the township that makes the unit almost 10 lakhs more expensive than that provided by the housing schemes. The fiscal benefits of the township policy regarding service tax waivers are not quite implemented here.

\begin{tabular}{|l|l|l|l|}
\hline For 3 bhk unit & Bakeri city & Godrej garden city & per sq ft \\
\hline Rate per sq. ft. & 4050 & 3690 & \\
\hline Unit cost & 7350750 & & \\
\hline Area of the unit (3bhk) sq.ft & 1815 & 1800 & \\
\hline Discount 15\% & 1102612 & & \\
\hline Net cost & 6248137 & 6642000 & \\
\hline Maintenance Advance & & 252000 & $140 \mathrm{rs}$ \\
\cline { 1 - 1 } Legal charges & & 10000 & \\
\cline { 1 - 1 } AMC charges & & 27,000 & $15 \mathrm{rs}$ \\
\hline Area Development charges & & 180000 & $100 \mathrm{rs}$ \\
\hline Club house charges & & 20000 & \\
\hline Total & 6792637.00 & 7131000 & 13 \\
\hline Service tax & 245893.4594 & 863460 & \\
\hline Registration fees @ 1\% & 67926.37 & 71310 & \\
\hline Stamp duty & 307500 & 325458 & \\
\hline Total & 7413956.83 & 8391228 & \\
\hline
\end{tabular}

\section{CONCLUSION AND FINDINGS}

Even though Gujarat has a single window process, there are delays in the project due to rigid scrutiny and approval process. Godrej garden city was initially rejected and then approved in 2009.This rejection happened at the state level intervention. The single widow process states, to authorize a development commissioner to exercise powers equivalent to that of a state government body. Under the township policy, the state government appoints a prescribed officer different for townships developed in Municipal areas and those developed within AUDA or AMC boundary. Within 30 days from the receipt of application they have to recommend the state to either approve or reject the township approval. However the screening committee comprising of principle secretary, $\mathrm{UDD}^{\mathrm{vii}}$ principle secretary, Finance department, Officer on special duty, UDD, again reviews the proposal and then the state government gives the gazette notification. Townships require fast track approval process to allow optimal return on capital. Since the DP has demarcated zones for residential areas, the stand alone schemes do not need a further approval. In a way, allowing the townships to come up in any zone, makes the process longer. If the DP allotted special zones where the townships can be developed, it would not have to go through the process of gazette notification from the state government. The zone would be cleared at the time of DP plan approval process. This would reduce the process by 1 year. Next obstacle is the Environmental clearance which takes 8 months to 1 year.

High taxes and development charges, increase the selling price of the property, thereby narrowing down its target group. Instead of a fixed maintenance period of 7 years, the policy can make it flexible like in the Bakeri city. This would reduce the maintenance charge for the townships. Scheme wise development and possession is faster than phase wise development. This is because every phase in the township also has a commercial or an institutional development to be completed before launching it and applying for BU. Reforms in the township policies, also cause delay in the process. Factors like minimum area, maximum permissible FSI were changed in 
the Godrej garden city when the policy was revised in 2009. This prolonged the process by 6 months in negotiations with the government. They also increased the residential area from $65 \%$ to $87 \%$ in the revised plan. Housing schemes have the benefit of flexible land use, whereas the townships have to stick to the policy regulations. Entering in a PPP agreement with the government would benefit a township, in terms of external infrastructure connectivity, extension of land and faster approval process. For PPP project, the mobilization of resources also becomes speedy.

\section{REFERENCES}

[1] (n.d.). Retrieved from www.cseindia.org.

[2] (n.d.). Retrieved from www.urbannewsdigest.in

[3] Utpal Sharma. (2007-2008). Integrated townships towards development of the city: a case of Pune. Thesis.

[4] ww.cushmanwakefield.com. (n.d.)

[5] www.nhb.org.in. (n.d.).

[6] www.mhupa.gov.in. (n.d.)

[7] www.spa.ac.in. (n.d.).

[8] Wakefield, A. C. (April 2014). CHALLENGES \& OPPORTUNITIES FOR THE HOUSING SECTOR IN URBAN INDIA. Research Publication.
[9] (November 2010). Working with the Market, Approach to Reducing Urban Slums in India. The World Bank, Finance, Economics and Urban Development Department.

[10] (2015). Retrieved from www.ficci.com

[11] Alleviation, M. о. (2011-2012). Annual Report.

[12] Bank, N. H. (2012). Trend and Progress of Housing in India.

[13] Darshini Mahadevia, R. D. (September ,2014). City Profile:Ahmedabad.

[14] ITPI. (199). Urban Development Plan Formulation \& Implmentation Guidelines. New Delhi: Ministry of Urba Affairs and Employment,GoI.

[15] LaSalle, J. L. Affordable Housing in India.

[16] Pritam P Hans. (July 2013). Going to Town. MoneyToday .

[17] Roy, M. (2006-2007). Comparative assessment of townships in real estate market. Thesis, Ahmedabad.

[18] Today, I. (n.d.). businesstoday.intoday.in.

${ }^{\mathrm{i}}$ GUDC-Gujarat Urban Development Corporation is positioned to facilitate by assisting state government and existing agencies in formulation of policy, institutional capacity building and project implementation and to assist in the funding and implementation process.

${ }^{i i}$ EWS- Economically Weaker Section-Households with monthly income upto 5000 Rs. as revised by the Ministry of Housing and Urban Poverty Alleviation, Government of India

iii LIG- Low Income Group-Households with monthly income between 5001 Rs.- 10,000 Rs. as revised by Ministry of Housing and Urban Poverty Alleviation, Government of India

${ }^{\text {iv }}$ AMC- Ahmedabad Municipal Corporation is the local self government of the city which emerged as the first people's representative council or democratic body in India. It is responsible for the civic infrastructure and administration of the city.

${ }^{v}$ AUDA- Ahmedabad Urban Development Authority (AUDA) was established by the State Government of Gujarat. The prime objective of the AUDA's formation was to carry out the sustained planned development of the area falling outside the periphery of Ahmedabad Municipal Corporation. In addition to the area falling under the Ahmedabad Municipal Corporation's limit, it also includes 5 growth centers and 169 villages of Ahmedabad district.

${ }^{v i}$ GTPUDA ACT-Gujarat Town Planning and Urban Development Act

${ }^{v i i}$ UDD- Urban Development Department 